\title{
LOW MOLECULAR WEIGHT PROTEINURIA IN CHILDREN WITH DISTAL RENAL TUBULAR ACIDOSIS
}

\author{
Shpetim Salihu ${ }^{1}$, Katerina Tosheska ${ }^{2}$, Svetlana Cekovska ${ }^{2}$, \\ Zoran Gucev ${ }^{3}$, Momir Polenakovic ${ }^{4}$, Velibor Tasic ${ }^{3}$ \\ ${ }^{1}$ Department of Neonatology, University Clinical Center, Prishtina, Kosovo \\ ${ }^{2}$ Institute of Medical and Experimental Biochemistry, Medical School Skopje, Republic of Macedonia \\ ${ }^{3}$ University Children's Hospital, Medical School Skopje, Republic of Macedonia \\ ${ }^{4}$ Macedonian Academy of Science and Arts, Skopje, Republic of Macedonia
}

Corresponding author: Prof. Dr. Velibor Tasic, University Children's Hospital, 17 Vodnjanska 1000 Skopje,, Macedonia, Tel.: +389 2314721, e-mail: vtasic2003@gmail.com

\begin{abstract}
Distal renal tubular acidosis (dRTA) (MIM \#267300, \#602722 and \#179800) is a rare inherited tubulopathy characterized by the inability of the distal tubule to acidify the urine with consecutive systemic acidosis. The clinical features include polyuria, polydipsia, poor appetite, failure to thrive, short stature and rickets. Prominent biochemical features are hypokalemia, hypercalciuria and hypocitraturia. There are reports on patients who presented with unusual biochemical features such as low molecular proteinuria, hypophosphatemia, hypouricemia, generalized hyperaminioaciduria, hyperoxaluria and other making diagnostic confusion to the clinicians. In this work, we report on a series of 8 children with clinically, biochemically and genetically proven dRTA who present with low molecular proteinuria at the disease onset. With metabolic compensation of the disease, there was complete resolution of the low molecular weight protenuria and other proximal tubular abnormalities in all children. Late recognition of the disease with long standing hypokalemia and acidosis may result in abnormal expression and function of the transporters in the proximal tubules. Sodium dodecyl sulphate polyacrylamide gel electrophoeresis is an accurate method for detection and follow up of patients with low molecular weight proteinuria.
\end{abstract}

Keywords: distal renal tubular acidosis, low molecular weight proteinuria, SDS-PAGE

\section{INTRODUCTION}

Distal renal tubular acidosis (MIM \#267300, \#602722 and \#179800) is a rare inherited tubulopathy characterized by the inability of the distal tubule to acidify the urine with consecutive systemic acidosis. The clinical features include polyuria, polydipsia, poor appetite, failure to thrive, short stature and rickets. Prominent biochemical features are hypokalemia, hypercalciuria and hypocitraturia. Ultrasound investigation of the kidneys reveals presence of medullary nephrocalcinosis and stones. The disease may be associated with early or late sensorineural hearing loss depending on the mutated $\mathrm{H}+\mathrm{ATPase}$ genes. [1, 2, 3] There are reports on patients who presented with unusual biochemical features such as low molecular proteinuria, hypophosphatemia, hypouricemia, generalized hyperaminioaciduria, hyperoxaluria and other making diagnostic confusion to the clinicians. [4, $5,6,7]$ We have already reported two infants with atypical presentation of dRTA, who showed signs of proximal renal tubular dysfunction. In this paper, we present a small series of Macedonian children with dRTA with emphasis on the presence of low molecular proteinuria at diagnosis. [4] 


\section{PATIENTS AND METHODS}

The diagnosis of dRTA was established on the basis of systemic acidosis $(\mathrm{HCO} 3<20 \mathrm{mmol} / \mathrm{l})$ with simultaneous inappropriate high urine $\mathrm{pH}$ determined with an electrode $(\mathrm{pH}>5.30)$. All children underwent thorough physical examination with measurement of the weight and height and searching for signs of rickets. Audiometry was performed for assessment of the hearing status. In infants, brainstem auditory evoked potential study was performed. The kidneys were evaluated with ultrasound scanning for the presence of nephrocalcinosis and stones.

Standard biochemistry included complete blood count, serum electrolytes, uric acid, acid base status, alkaline phosphatase and parathormone. Twenty four hour urine samples were obtained for assessment of urine electrolyte excretion, uric acid, citrate, oxalate, amino acids and low molecular weight proteins. Hypercalciuria was defined as $>4 \mathrm{mg} / \mathrm{kg} / \mathrm{d}$, hyperoxaluria $>0.5$ $\mathrm{mmol} / 1.73 \mathrm{~m} 2 / \mathrm{d}$, hypocitraturia $<220 \mathrm{mg} / \mathrm{d}$. In infants and non-toilet trained children, spot urine samples were obtained in which the ratio of calcium/creatinine, oxalate/creatinine and citrate/ creatinine were determined and compared with referent values for the age. $[8,9,10]$

Low molecular weight proteinuria was assessed with SDS-PAG electrophoresis according to the method described by Görg et al. [11] In addition, single urinary markers such as beta-2 microglobulin, alfa-1 microglobulin were measured and compared to referent values. [12, 13, 14]

Genetic tests for H+ ATP-ase genes (ATP6V1B1 and ATP6V0A4) and anion exchanger 1 gene (SLC4A1) were performed in referent laboratories.

This study is a part of the $\mathrm{PhD}$ thesis (S.S) and was approved by the Ethical Committee of the Medical School Skopje. All participants signed the informed consent.

\section{RESULTS}

Eight children were included in this study. Their basic demographic, clinical and biochemical data are presented in table 1. All fulfilled diagnostic criteria for distal RTA. Six children had nephrocalcinosis, one child had single kidney stone and one child had normal kidney ultrasound scan. Molecular diagnosis was confirmed in 7 patients, only one patient was tested negative for the respective genes. Low molecular proteinuria was present in all six children. It was characterized with the presence of fractions with the size ranging from $10-67 \mathrm{kD}$ (figure 1). It correlated with the presence of abnormal urinary levels of beta-2 microglobulin and alfa-1-microglobulin where tested. In seven children there were additional serum and urine abnormal parameters as a result of proximal tubular dysfunction. In one girl proximal tubular dysfunction was so severe so that initially she was considered to have Fanconi syndrome. Low molecular proteinuria resolved in all children after one to eight months, as well as other signs of proximal tubular dysfunction (hyperaminoaciduria, hypophoshatemia, hyerphosphaturia, hypouricemia, hyperuricosuria).

Table 1. Clinical biochemical and genetic features of 8 children with distal renal tubular acidosis

\begin{tabular}{|c|c|c|c|c|c|c|c|c|}
\hline 总 & 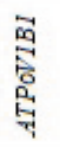 & 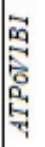 & 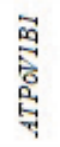 & 沀 & 雿 & प्: & 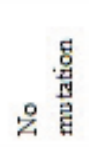 & 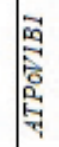 \\
\hline 骂 & $\cdots$ & $\ldots$ & 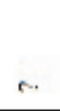 & $\ldots$ & $\infty$ & 只 & $\infty$ & 会 \\
\hline 竎 & $\ldots$ & $\ldots$ & $z$ & z & $\infty$ & 量 & $c$ & 会 \\
\hline 费 & $c$ & $\ldots$ & z & z & $\infty$ & $\ldots$ & 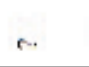 & 县 \\
\hline 露 & 䓌 & 㫥 & $\stackrel{\infty}{\stackrel{9}{్}}$ & 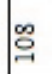 & $\vec{\exists}$ & $m$ & $\stackrel{8}{\circ}$ & $\cong$ \\
\hline a, & 学 & 豙 & $\underset{\substack{\infty \\
0}}{0}$ & Oે & so & 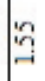 & $\stackrel{\infty}{\circ}$ & 思 \\
\hline | & 5 & $E$ & $\underset{\mathrm{Z}}{\mathrm{g}}$ & 具 & 悬 & 县 & $\mathrm{S}$ & 县 \\
\hline 展 & 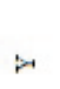 & $i r$ & $i$ & $i$ & $i$ & $i-1$ & $i$ & $i-$ \\
\hline 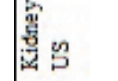 & 乥 & 岁 & 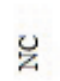 & z & 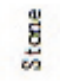 & 设 & $z$ & لِ \\
\hline 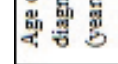 & in & $m$ & $\mathrm{C}$ & in & $m$ & $\stackrel{\infty}{\circ}$ & in & 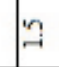 \\
\hline ઝૂ & $\ddot{z}$ & $\nexists$ & 山 & 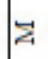 & $z$ & 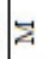 & 山 & 山 \\
\hline 产 & 8 & $\mid \begin{array}{r}\pi_{1} \\
\vdots\end{array}$ & 范 & 誌 & 兑 & ळ & 㐫 & 邑 \\
\hline
\end{tabular}




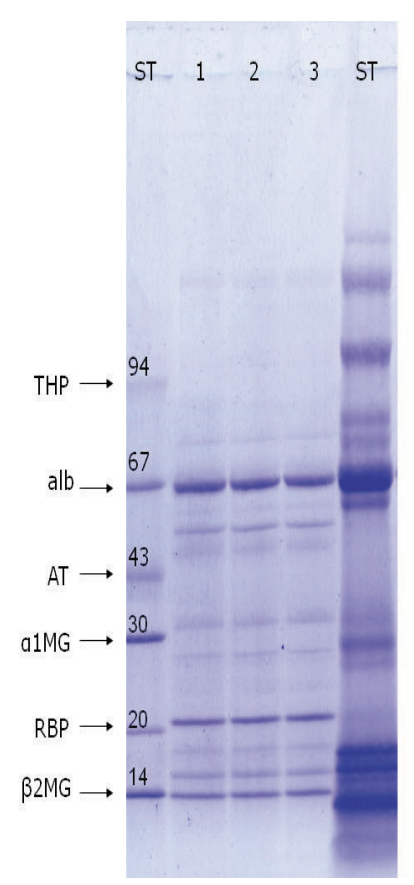

Figure 1. Low molecular proteinuria in a patient with distal renal tubular acidosis.

Legend to figure 1. ST-standard; Lane 1,2,3 patient's elepherograms in triplicate; THP-Tamm Horsfall protein; alb-albumin; AT-antitrypsin; a1MG-alpha1 microglobulin, RBP-retinol binding protein. B2MG-beta2 microglobulin

\section{DISCUSSION}

In this work we studied the presence of low molecular weight proteins in children with clinically, biochemically and genetically well defined distal renal tubular acidosis. All children had LMWP at diagnosis and this correlated with increased urinary levels of beta- 2 microglobiulin and alfa-1 microglobulin. It is of note that sodiu dodecyl sulphate polyacrylamide gel electrophoresis (SDS-PAGE) is a relatively old method for differentiation of proteinurias but unfortunately neglected in the nephrological practice. [15] It was implemented in the clinical practice in the 80 s and 90 s of the previous century and was pretty popular in Germany. $[16,17,18]$ This method enables differentiation between tubular and glomerular proteinuria and further analysis (selective, non-selective glomerular), tubular (complete, incomplete) or mixed glomerulo/tubular. We have successfully used it for differentiation of glomerular from non-glomerular hematurias and for analysis of functional proteinurias (orthostatic, exercise induced proteinuria). [19, 20, 21] Analysis of the elepherograms enables pan- oramic investigation of various fractions according to their molecular weight and more subtle characterization of proteinuria (e.g. non selective glomerular with incomplete tubular proteinuria). The investigation of single urinary proteins may be helpful but offers limited information. The combination of 3 or more markers may be more sensitive for definition of the proteinuria type, but increases the costs and makes the analysis difficult for clinicians without experience in urinary protein biochemistry. Therefore, several expert (computerized) systems were developed to enhance the analysis of the data. Lun et al analyzed the values of different expert systems for characterization of proteinuria in children with various renal diseases. [22] They found that the UPES system has high accuracy for detection of LMWP proteinuria; in 19 children with clear clinically and pathologically defined tubulointersitial diseases they detected tubular proteinuria in 16/19 and in additional 3/19 mixed glomerulotubular proteinuria.

We used SDS-PAGE to follow our children with dRTA. With metabolic compensation there was disappearance of LMWP in the period between 2 and 8 months. The presence of LMWP proteinuria may raise differential diagnostic dilemma with Dent's disease in which there is low molecular proteinuria, hypercalciuria and mild acidosis. [23] Dent disease affects males and LMWP proteinuria is persistent and not amenable to any treatment.

The majority of children in our series were diagnosed late. It seems that long lasting hypokalemia and acidosis affect the expression and function of various transporters in proximal tubules resulting in compromise of reabsorption of low molecular weight proteins, phosphate, uric acid and aminoacids. [24] In addition, we and others have evidenced hyperoxaluria at the disease onset, its mechanism has not yet been clarified. $[4,6]$

\section{CONCLUSIONS}

Herein we presented a series of 8 children with dRTA who present with low molecular proteinuria at the disease onset. It seems that late recognition of the disease with long standing hypokalemia and acidosis may result in abnormal expression and function of the transporters in the proximal tubules. With metabolic compensation 
of the disease, there is complete resolution of the low molecular weight protenuria and other proximal tubular abnormalities. SDS-PAG electrophoeresis is an accurate method for detection and follow up of patients with LMWP.

\section{Acknowledgment}

We wish to thank Dr. Hae Il Cheong (Department of Pediatrics, Seoul National University Children's Hospital, Seoul, Korea) for mutational analysis of the ATP6V1B1 and ATP6V0A4) genes and to Dr. John A Sayer (Institute of Genetic Medicine, Newcastle University, Newcastle, United Kingdom) for mutational analysis of the SLC4A1gene.

\section{REFERENCES}

1. Karet FE, Finberg KE, Nelson RD, Nayir A, Mocan H, Sanjad SA, Rodriguez-Soriano J, Santos F, Cremers CW, Di Pietro A, Hoffbrand BI, Winiarski J, Bakkaloglu A, Ozen S, Dusunsel R, Goodyer P, Hulton SA, Wu DK, Skvorak AB, Morton $\mathrm{CC}$, Cunningham MJ, Jha V, Lifton RP. Mutations in the gene encoding B1 subunit of H+-ATPase cause renal tubular acidosis with sensorineural deafness. Nat Genet. 1999; 21: 84-90.

2. Stover E, Borthwick KJ, Bavalia C, Eady N, Fritz DM, Rungroj N, Giersch AB, Morton CC, Axon PR, Akil I, Al-Sabban EA, Baguley DM, Bianca S, Bakkaloglu A, Bircan Z, Chauveau D, Clermont MJ, Guala A, Hulton SA, Kroes H, Li Volti G, Mir S, Mocan H, Nayir A, Ozen S, Rodriguez Soriano J, Sanjad SA, Tasic V, Taylor CM, Topaloglu R, Smith AN, Karet FE. Novel ATP6V1B1 and ATP6V0A4 mutations in autosomal recessive distal renal tubular acidosis with new evidence for hearing loss. J Med Genet. 2002; 39: 796-803.

3. Vargas-Poussou R, Houillier P, Le Pottier N, Strompf L, Loirat C, Baudouin V, Macher MA, Déchaux M, Ulinski T, Nobili F, Eckart P, Novo R, Cailliez M, Salomon R, Nivet H, Cochat P, Tack I, Fargeot A, Bouissou F, Kesler GR, Lorotte S, Godefroid N, Layet V, Morin G, Jeunemaître X, Blanchard A. Genetic investigation of autosomal recessive distal renal tubular acidosis: evidence for early sensorineural hearing loss associated with mutations in the ATP6V0A4 gene. J Am Soc Nephrol. 2006; 17: 1437-43

4. Tasic V, Korneti P, Gucev Z, Hoppe B, Blau N, Cheong HI. Atypical presentation of distal renal tubular acidosis in two siblings. Pediatr Nephrol. 2008; 23: 1177-81.
5. Copelovitch L, Kaplan BS. An expanded syndrome of dRTA with hearing loss, hyperoxaluria and beta2-microglobulinuria. NDT Plus. 2010; 3 : 439-42.

6. Mehler K, Stapenhorst L, Beck B, Hoppe B. Hyperoxaluria in patients with primary distal renal tubular acidosis. Pediatr Nephrol. 2003; 18: 722-3.

7. Igarashi T, Kawato H, Kamoshita S. Reversible low-molecular-weight proteinuria in patients with distal renal tubular acidosis. Pediatr Nephrol. 1990; 4: 593-6.

8. Reusz GS, Dobos M, Byrd D, Sallay P, Miltényi M, Tulassay T. Urinary calcium and oxalate excretion in children. Pediatr Nephrol. 1995; 9:39-44.

9. Sargent JD, Stukel TA, Kresel J, Klein RZ. Normal values for random urinary calcium to creatinine ratios in infancy. J Pediatr. 1993; 123: 393-7.

10. Kirejczyk JK, Porowski T, Konstantynowicz J, Kozerska A, Nazarkiewicz A, Hoppe B, Wasilewska A. Urinary citrate excretion in healthy children depends on age and gender. Pediatr Nephrol. 2014; 29: 1575-82.

11. Görg A, Postel W, Weser J, Schiwara HW, Boesken WH. Horizontal SDS electrophoresis in ultrathin pore-gradient gels for the analysis of urinary proteins. Science Tools. 1985; 32: 5-9.

12. Hibi Y, Uemura O, Nagai T, Yamakawa S, Yamasaki Y, Yamamoto M, Nakano M, Kasahara K. The ratios of urinary $\beta 2$-microglobulin and NAG to creatinine vary with age in children. Pediatr Int. $2015 ; 57: 79-84$.

13. Tsukahara H, Hiraoka M, Kuriyama M, Saito M, Morikawa K, Kuroda M, Tominaga T, Sudo M. Urinary alpha 1-microglobulin as an index of proximal tubular function in early infancy. Pediatr Nephrol. 1993; 7: 199-201.

14. Grillenberger A, Weninger M, Lubec G. Determination of urinary low molecular weight proteins for the diagnosis of tubular damage. Padiatr Padol. 1987; 22: 229-34.

15. Lau YK, Woo KT. SDS-PAGE is underutilized as a tool for investigating renal patients. Nephron. 2002; 90: 227-9.

16. Lubec D, Grillenberger A, Weninger M, Lubec G. Value of SDS-polyacrylamide gel electrophoresis, small molecular weight proteins and alpha-1-acid glycoprotein for the diagnosis of tubular damage. Padiatr Padol. 1987; 22: 319-24.

17. Ehrich JH, Wurster U. Differentiation of proteinurias with electrophoresis. Pediatr Nephrol. 1991; 5: 376-8.

18. Brocklebank T, Cooper EH, Richmond K. Sodium dodecyl sulphate polyacrylamide gel electrophoresis patterns of proteinuria in various renal 
diseases of childhood. Pediatr Nephrol. 1991; 5: $371-5$

19. Tasic V, Korneti P. SDS-PAGE of urinary proteins for detection of nonglomerular hematurias. Nephron. 2001; 88: 387-8.

20. Korneti PG, Tasic VB, Jovanoska LK, Korneti BK. Difference between orthostatic and march functional proteinuria by application of stress tolerance test and SDS-PAGE. Clin Chim Acta. 2000; 297: 145-53.

21. Tasic V, Korneti P, Gucev Z, Korneti B. Stress tolerance test and SDS-PAGE for the analysis of urinary proteins in children and youths. Clin Chem Lab Med. 2001; 39: 478-83.
22. Lun A, Suslovych M, Drube J, Ziebig R, Pavicic L, Ehrich JH. Reliability of different expert systems for profiling proteinuria in children with kidney diseases. Pediatr Nephrol. 2008; 23: 285-90.

23. Lloyd SE, Pearce SH, Günther W, Kawaguchi H, Igarashi T, Jentsch TJ, Thakker RV. Idiopathic low molecular weight proteinuria associated with hypercalciuric nephrocalcinosis in Japanese children is due to mutations of the renal chloride channel (CLCN5). J Clin Invest. 1997; 99: 96774.

24. Watanabe T. Proximal renal tubular dysfunction in primary distal renal tubular acidosis.Pediatr Nephrol. 2005; 20: 86-8.

\title{
Резиме
}

\section{НИСКО МОЛЕКУЛАРНА ПРОТЕИНУРИЈА КАЈ ДЕЦА СО ДИСТАЛНА РЕНАЛНА ТУБУЛСКА АЦИДОЗА}

\author{
Шпетим Салиху ${ }^{1}$, Катерина Тошеска $^{2}$, Светлана Цековска ${ }^{2}$, \\ Зоран Гучев ${ }^{3}$, Момир Поленаковиќ ${ }^{3}$ Велибор Тасиќ ${ }^{4}$
}

${ }^{1}$ Неонатолошки оддел, Универзитетски клинички центар Приштина, Косово

${ }^{2}$ Институт за медицинска и експериментална биохемија, Медициснки факултет, Скопје, Република Македонија

${ }^{3}$ Универзитетска детска болница, Медицински факултет, Скопје, Република Македонија

${ }^{4}$ Македонска академија на науките и уметностите, Скопје, Република Македонија

Дистална ренална тубулска ацидоза (дРТА) (МIM \#267300, \#602722 и \#179800) е ретка наследна тубулопатија, која се карактеризира со неспособност на дисталниот тубул да ја ацидифицира урината и консекутивна системска ацидоза. Клиничката слика вклучува полиурија, полидипсија, намален апетит, слабо напредување, низок раст и рахитис. Истакнати биохемиски црти се хипокалемија, хиперкалциурија и хипоцитратурија. Постојат презентирани описи на пациенти со невообичаени биохемиски знаци, какви што се нискомолекуларна протеинурија, хипофосфатемија, хипоурикемија, генерализирана хипераминоацидурија, хипероксалурија и други, кои водат до дијагностичка конфузија кај клиничарите. Во овој труд ние прикажуваме серија од осум деца со клинички, биохемиски и генетски докажана дРТА, кои се презентираа со нискомолекуларна протеинурија на почетокот на болеста. Со метаболичка компензација на болеста дојде до комплетна резолуција на нискомолекуларната протеинурија и на другите проксимални тубулски абнормалности кај сите деца. Доцното препознавање на болеста, долготрајната хипокалемија и ацидозата резултираа со абнормалната експресија и функција на транспортерите во проксималните тубули. Натриум додецил сулфат полиакриламид гел електрофорезата е сигурен метод за детекција и за следење на пациентите со нискомолекуларна протеинурија. PAGE

Клучни зборови: дистална ренална тубулска ацидоза, нискомолекуларна протеинурија, SDS- 